\title{
Acalyptrate flies (Diptera) on glacial sand deposits in the Hlučínsko region (NE Czech Republic): most interesting records
}

\section{Jindřich R o há č e k}

\begin{abstract}
Acalyptrate flies (Diptera) on glacial sand deposits in the Hlučínsko region (NE Czech Republic): most interesting records. - Acta Mus. Siles. Sci. Natur. 65: 33-46, 2016.
\end{abstract}

\begin{abstract}
Records of six species of the families Ulidiidae, Anthomyzidae, Asteiidae, Milichiidae, Chloropidae and Curtonotidae from glacial sand deposits in the Hlučínsko region (NW Czech Republic) are presented and their association with sandy habitats are discussed. Two thermophilous and/or xerophilous species, Anthomyza elbergi Andersson, 1976 (Anthomyzidae) and Desmometopa discipalpis Papp, 1993 (Milichiidae) represent new additions to the fauna of the Czech Republic. Two psammophilous or psammobiont species, Eutropha variegata Loew, 1866 (Chloropidae) and Curtonotum anus (Meigen, 1830) (Curtonotidae) are recorded for the first time from Moravia and the Czech Silesia respectively, the latter from a locality lying on northern border of its distributional range. Also Asteia elegantula Zetterstedt, 1847 (Asteiidae) is first recorded from the Czech Silesia and Desmometopa discipalpis is recorded from its northernmost known locality. Information on microhabitats of these species and also the psammobiont Tetanops myopina Fallén, 1820 (Ulidiidae) in sandpits are provided and most of them were photographed alive. The origins of populations of these species on glacial sands in the Hlučínsko region are discussed and it is concluded that while Asteia elegantula and Eutropha variegata are widespread in the W Palaearctic, Curtonotum anus and Desmometopa discipalpis are distinctly of southern origin and, most interestingly, Tetanops myopina and Anthomyza elbergi seem to originate from northern Europe and may have reached this area already during the Saalian glaciation (cca 160000 ya).
\end{abstract}

Key words: Diptera, Ulidiidae, Anthomyzidae, Asteiidae, Milichiidae, Chloropidae, Curtonotidae, new records, psammophily, glacial sand deposits, Czech Republic (Moravia)

\section{Introduction}

The sand deposits in the Czech Silesia (NE part of the Czech Republic) that were formed in the area during Quaternary glaciations represent an interesting and, compared to their vicinity, a rather extreme habitat. Although it is known that ecosystems on sand have a highly specific insect fauna, little attention has hitherto been paid to their investigation in this area. Some data on a few interesting representatives of Diptera found on glacial sands in sandpits in the Czech Silesia have recently been presented by Roháček \& Ševčík (2013) in the popular book Př́roda Slezska (Nature of Silesia) but no systematic research of the fly fauna has hitherto been conducted there.

During the initial research of Diptera communities on glacial sand deposits in the Hlučínsko region (part of Czech Silesia, NE Czech Republic) in 2013 a number of interesting, mainly psammophilous, xerophilous and/or thermophilous species have been found, some of which proved to represent new additions to the Czech fauna of Diptera. One of these species, the psammobiont Tetanops myopina Fallén, 1820 (Ulidiidae: Otitinae), has already been treated in detail by Roháček (2015a) inasmuch as it obviously reached the NE Czech Republic already during the Saale glaciation (cca 160000 ya) and survived as a glacial relict on glaciolacustrine sands formed in this area up to the present. Just this interesting discovery initiated a more intensive field work on selected sandy habitats in the Hlučínsko region in 2015 which resulted in several other findings important from the faunistic and/or biogeographical point of view.

These records (covering taxa of the acalyptrate families Ulidiidae, Anthomyzidae, Asteiidae, Milichiidae, Chloropidae and Curtonotidae) are presented below to supplement information about the dipterous fauna of the Czech Republic (see checklists of these families 
by Kubík 2009; Máca 2009; Roháček 2009a-d), particularly with respect to contemporary preparation of a new version of the Checklist of Diptera of Czech Republic and Slovakia (electronic version 3). It is to remark that preliminary information on some of the most interesting flies occurring on glacial sands in the Hlučínsko region was presented orally at the 8th Central European Dipterological Conference, Kežmarské Žl’aby, Slovakia, 28.-30. September 2015, see also Roháček (2015b).

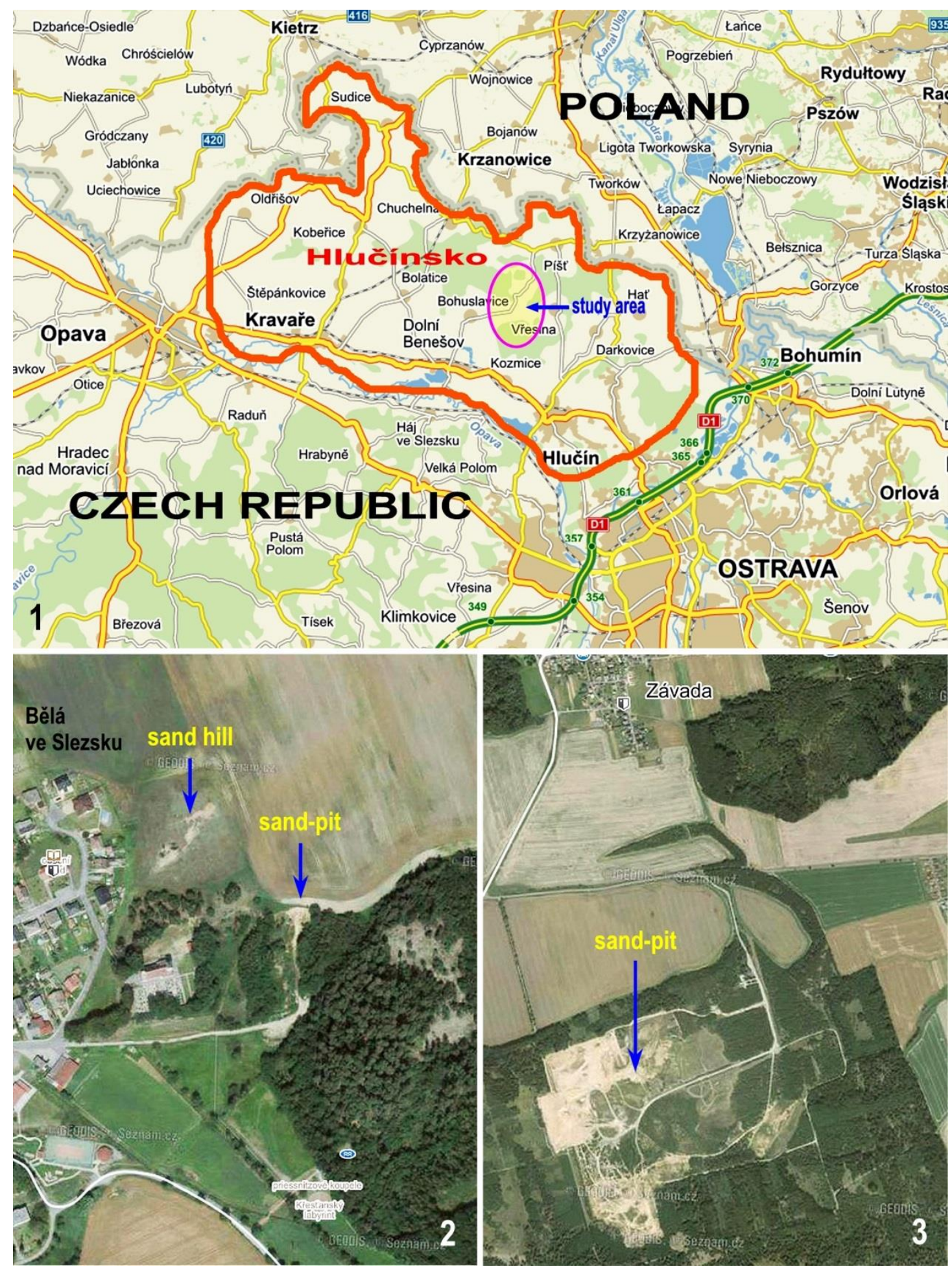

Figs 1-3: Maps. 1 - Hlučínsko region with situation of the study area (ellipse); 2 - aerial view of the abandoned sandpit and nearby sand hill in Bělá ve Slezsku; $\mathbf{3}$ - aerial view of the active sandpit Závada. Map sources: www.mapy.cz 


\section{Material and methods}

All the material examined is deposited in the collection of the Silesian Museum, Opava, Czech Republic (SMOC). The collected specimens were air-dried and mounted on pinned triangular cards in the course of the study but some of them were retained alive in plastic tubes to be photographed shortly after being captured in special glass boxes by means of a digital camera (Canon EOS 60D) with a macro lens (Canon MP-E 65 mm 1$5 \times$ ) and ring macro flash (Canon MR-14EX). After photography also these specimens were killed and mounted for subsequent identification. Where necessary male genitalia and female postabdomina were examined after detachment and dissection of the whole abdomina and all parts of them have been after examination transferred to small coalesced plastic tubes and pinned below the respective specimens; this is indicated by the abbreviation "genit.prep." in the list of material examined. Two types of binocular stereoscopic microscopes (Reichert, Olympus) and a compound biological microscope Jenaval were used for examination and identification. Habitat photographs were taken in the field by digital cameras Canon EOS 60D and Sony NEX-7.

Field work was performed in the Hlučínsko region (Fig. 1) in two localities with glacial sand deposits in 2013, viz. Bělá ve Slezsku (Fig. 2), 4958'25"N, 1809'05"E, cca 245 m (9.vii.2013) and Závada nr. Hlučín (Fig. 3), about 49 56'25"N, 1809'56"E, cca $265 \mathrm{~m}$ (9.vii. and 17.vii.2013). In 2015 the latter locality was visited once monthly from May to September (12.v., 24.vi., 28.vii., 20.viii., 10.ix.2015) to obtain more precise image of the dipterous community occurring in this large sandpit (for detailed description of this locality see Roháček 2015a). The flies were collected by sweeping over sparse low vegetation or bare sand; netting of individually observed specimens was also used.

\section{Results}

\section{ULIDIIDAE}

\section{Tetanops myopina Fallén, 1820}

Material examined: CZECH REPUBLIC: N Moravia: Závada nr. Hlučín 1.6 km S, 4956'25"N, 1809'56"E, $265 \mathrm{~m}$, sandpit, NW part, sweeping sparse vegetation on sand, 24.vi.2015, 4 $\bigcirc_{11}$; ; Závada nr. Hlučín $2 \mathrm{~km} \mathrm{~S}$,

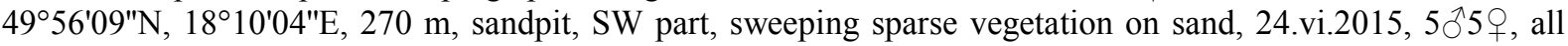
J. Roháček leg. et det. (SMOC).

Comments: Roháček (2015a) published the first Czech records of this largely maritime species living on coastal sand dunes from the sandpit Závada nr Hlučín based on specimens collected in 2013. The subsequent more detailed field work in this locality in 2015 revealed additional occurrence spots and demonstrated that Tetanops myopina survives there in a stable inland population. In May no adults were ascertained but in June (see material examined) they occurred in numbers (some 60-70 specimens netted but only the above 25 retained for collection). Interestingly, towards the end of June (on June 28) no more specimens were caught, although in 2013 a series was collected on June 9 and June 17, see Roháček (2015a). Thus, T. myopina seems to have a relatively short flight period in this locality, ranging from about mid June to mid July. Its association with loose sand overgrown by sparse Calamagrostis epigejos has been confirmed also in new spots, see for example the microhabitat on Fig. 4 shared with another psammobiont species, Aspistes berolinensis Meigen, 1818 (Scatopsidae) (Fig. 5).

\section{ANTHOMYZIDAE}

\section{Anthomyza elbergi Andersson, 1976}

Material examined: CZECH REPUBLIC: N Moravia: Bělá nr. Chuchelná $0.5 \mathrm{~km} \mathrm{E}, 4^{\circ} 58^{\prime 2} 6^{\prime \prime} \mathrm{N}, 1^{\circ} 09^{\prime} 05^{\prime \prime} \mathrm{E}$,

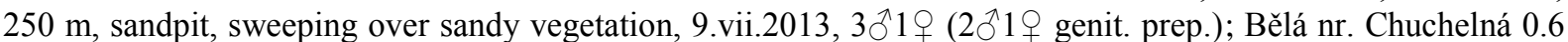
km E, 49॰58'39"N, 1808'49"E, 265 m, holt, sweeping Calamagrostis epigejos in sandy meadow, 9.vii.2013, $1 \delta^{\lambda}$ (genit. prep.); Závada nr. Hlučín 2 km S, 4956'09"N, 18¹0'04"E, 270 m, sandpit, SW part, sweeping over sand \& sparse vegetation on sand, 24.vi.2015, $1 \overbrace{}^{\Uparrow}$ (genit. prep.), all J. Roháček leg. et det. (SMOC). 
Biology: A. elbergi is probably a phytosaprophagous species associated with graminoids, preferably grasses (see Roháček 2009e), most commonly occurring in drier grassland habitats including clearings in and margins of forests (Roháček 2006). Andersson (1976) suggested Deschampsia caespitosa, Avenella flexuosa and Molinia caerulea as probable host plants of the species. There are rearing records from several more species of grasses and also from Carex elongata by Panteleeva $(1997,2005)$ and Panteleeva \& Razvorotnev (1996) from Russia (all as Anthomyza sordidella) but these data are not wholly reliable due to possible misidentifications (Roháček 2009e: 138). Anyway, the association of the species with grasses in generally dry habitats seems to be distinct and was also confirmed in two sandpits under study where several specimens were swept from grasses (mainly Calamagrostis epigejos) growing on sand (Fig. 6).

Distribution: This transpalaearctic species seems to be limited to the northern belt of the Palaearctic Region. It has been recorded from Ireland, Great Britain (Wales, England, Scotland), Germany, Poland, Norway, Sweden, Lithuania, Latvia, Estonia, Russia (CET, NET, WS, ES, FE), Japan and North Korea, see Roháček (2006, 2009e). Southernmost European findings (Roháček 2006) of A. elbergi have been known from Great Britain, N Germany (Schleswig-Holstein) and NE Poland (Białowieża). Consequently, the above (first) records from the Czech Republic represent a new southernmost occurrence limit of distribution this species in Europe.

Comments: Because of the author's long-lasting research of Anthomyzidae in the Czech Republic the finding A. elbergi was really unexpected in the country. However, it is to stress that the dry and sandy habitats have hitherto not been specially sampled for Anthomyzidae in this region so that the species may have passed unnoticed for a long time. Despite this fact $A$. elbergi probably has only relict, localised populations in Central Europe which could survive here after the last glaciation, similarly as is discussed for Tetanops myopina by Roháček (2015a).

\section{ASTEIIDAE}

\section{Asteia elegantula Zetterstedt, 1847 (Fig. 8)}

Material examined: CZECH REPUBLIC: N Moravia: Závada nr. Hlučín 1.6 km S, 4956'25"N, 1809'56"E, $265 \mathrm{~m}$, sandpit, NW part, sweeping over sand \& sparse vegetation on sand, 24.vi.2015, 19; N Moravia: Závada nr. Hlučín $2 \mathrm{~km} \mathrm{~S}, 49^{\circ} 56^{\prime} 09^{\prime \prime} \mathrm{N}, 18^{\circ} 10^{\prime} 04^{\prime \prime} \mathrm{E}, 270 \mathrm{~m}$, sandpit, SW part, sweeping over sand \& sparse vegetation on sand, 24.vi.2015, 19, all J. Roháček leg. et det. (SMOC, photographed).

Biology: The life history of $A$. elegantula remains practically unknown. Adults can be swept from vegetation on sunny margins of mainly lowland deciduous or mixed forests and groves (cf. Roháček \& Barták 2001). Larvae are probably (phyto)saprophagous microbial grazers (Marshall 2012) as in other Asteia species (Papp 1998a) and can develop in rotting plant material. A. elegantula had not been expected to occur in the above sandpit because the species was unknown in the Hlučínsko area and another species of the genus, A. concinna Meigen, 1830, proved to be a dominant species in sandy habitats there (being most abundant in growths of Calamagrostis epigejos).

Distribution: A Palaearctic species ranging from Spain to Far East of Russia (Carles-Tolrá 2013a). It is uncommon to rare in the Czech Republic and restricted to lower altitudes (Roháček et al. 2013). In this country it was recorded from several localities in lowlands of Bohemia (Roháček 1980, 1985; Roháček \& Barták 2001; Roháček et al. 2013) and S Moravia ((Roháček 1980, 1985, 1999). First records for N Moravia (the Czech Silesia). 


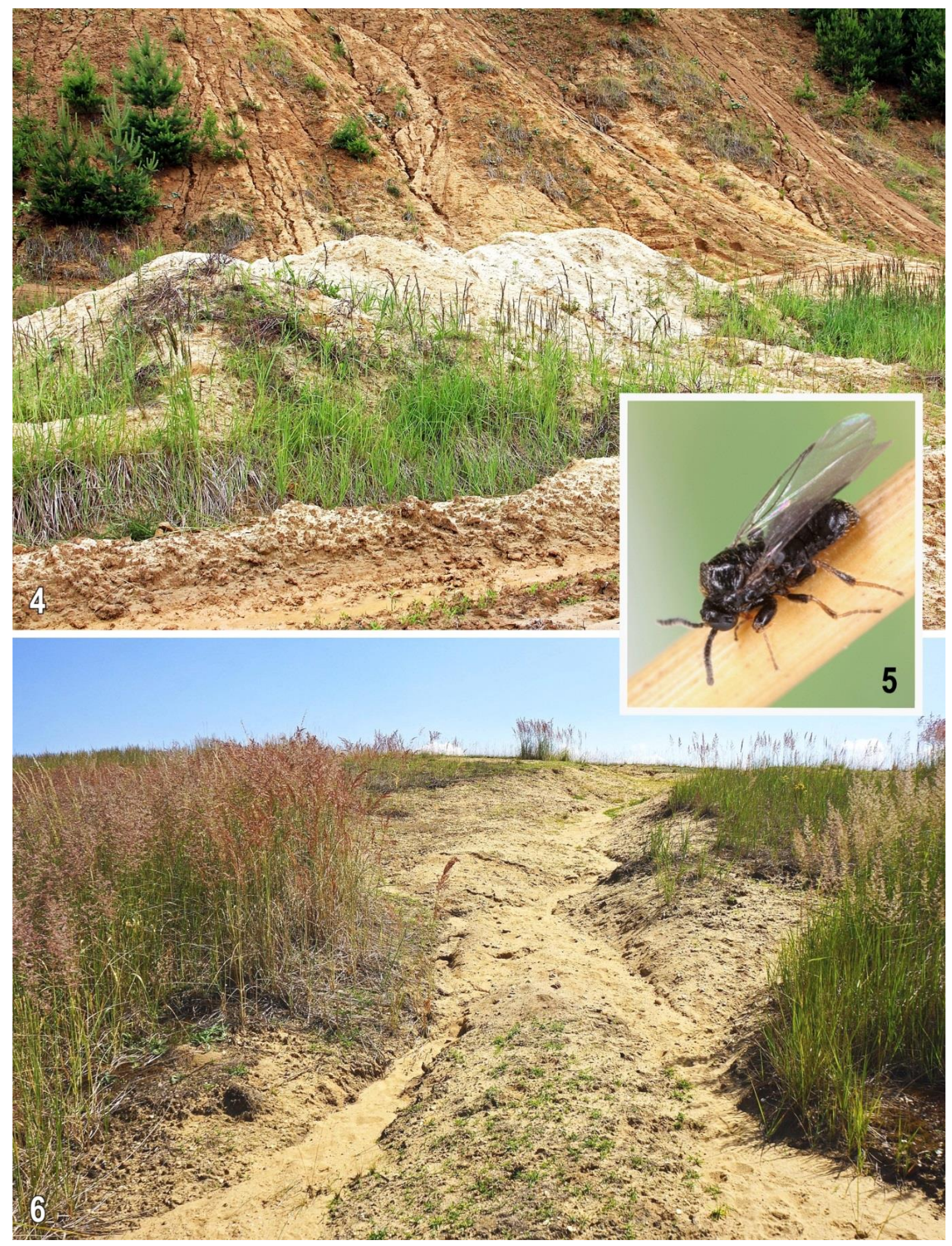

Figs 4-6: Sandy habitats and Aspistes berolinensis Meigen. 4 - a heap of fine sand in SW part of the Závada sandpit, a new occurrence spot of A. berolinensis and Tetanops myopina (Fallén); 5 - Aspistes berolinensis, male in dorsolateral view, body length $2.3 \mathrm{~mm} ; 6$ - Calamagrostis epigejos growth on sand hill near sandpit Bělá ve Slezsku, microhabitat of Anthomyza elbergi Andersson. Photo by J. Roháček. 
Comments: Asteia elegantula is the rarest species of Asteia in the Czech Republic. It certainly is not psammophilous; hence, its association with the sandpit habitat is probably due to its thermophily. The margins of young pine forest mixed with various deciduous trees and bushes (Fig. 8) covering most of the sandpit bottom can be its preferred habitat in the locality Závada.

\section{MILICHIIDAE}

\section{Desmometopa discipalpis Papp, 1993 (Fig. 7)}

Material examined: CZECH REPUBLIC: N Moravia: Závada nr. Hlučín 2 km S, 4956'09"N, 18¹0'04"E, 270 m, sandpit, SW part, sweeping over sand \& sparse vegetation on sand, 12.v.2015, 1ठ̂, J. Roháček leg. et det. (SMOC, identification confirmed by L. Papp and I. Brake).

Biology: Because of limited records, little is known about the habitat and life-history of $D$. discipalpis. Type specimens $(2 \Uparrow)$ were collected in warm forest steppe habitat (L. Papp, pers. comm. 2015). Brake (2009) reported $1 \delta^{\Uparrow} 1 q$ reared from a rotting poplar tree with Cossus in Stuttgart and mentioned that also specimens $\left(2{ }^{\Uparrow}\right)$ recorded by Sabrosky (1983: 15) as "Desmometopa sp. H" from Moscat in Algeria belong in fact to D. discipalpis and were also reared from "des galerie du Cossus". These data seem to indicate that D. discipalpis is a saprophagous species developing in rotten wood and/or excrement of Cossus. In addition, Brake (2010) recorded $1 \delta^{\lambda}$ caught in a wine-baited trap on an oak tree at Kerkini lake in Greece. The available habitat data and distribution (see below) demonstrate that it is a thermophilous species. The only male from the Závada sandpit was swept from low vegetation on sand at young pine forest mixed with birch, sallow and some other deciduous trees or bushes (Fig. 9). Adults of D. discipalpis were found/reared in May (Papp 1993; Brake 2009; material examined), June (Brake 2010) and August (see Brake: http://milichiidae.info/ taxonomy/ term/326/specimens).

Distribution: This insufficiently known species was originally described by Papp (1993) from Hungary (Tihany) and subsequently recorded by Brake (2009) from Germany (Stuttgart) and Algeria (Moscat) and by Brake (2010) from Greece (Kerkini lake). Hence, the above record (first from the Czech Republic) represents a new northernmost distribution limit of $D$. discipalpis.

Comments: This is an example of a species which is not sand-loving but associated with a sand deposit at a relatively high latitude due to its thermophily. It may originate from southern areas of Europe similarly as Curtonotum anus reported below.

\section{CHLOROPIDAE}

\section{Eutropha variegata Loew, 1866 (Figs 10, 11)}

Material examined: CZECH REPUBLIC: N Moravia: Závada nr. Hlučín 1.6 km S, 4956'25"N, 1809'56"E, $265 \mathrm{~m}$, sandpit, NW part, sweeping over sand \& sparse vegetation on sand, 24.vi.2015, $2 \hat{\jmath} 19$, 28.vii.2015, 1ठ, 20.viii.2015, 2+; Závada nr. Hlučín 2 km S, 4956'09"N, 18¹0'04"E, 270 m, sandpit, SW part, sweeping over sand \& sparse vegetation on sand, 24.vi.2015, 2§1q, all J. Roháček leg. et det. (SMOC, 39 photographed).

Biology: Poorly known. Coastal sand dunes are considered the preferred habitat (Nartshuk \& Andersson 2013) of this species which is probably phytosaprophagous as a larva (Nartshuk 1987). Adults were found under leaves of sea sandwort Honckenya peploides (cf. Nartshuk \& Andersson 2013) but the fly is obviously not associated with the coastal dune habitat so closely as the related E. fulvifrons (Haliday, 1833). This is demonstrated by the inland records 

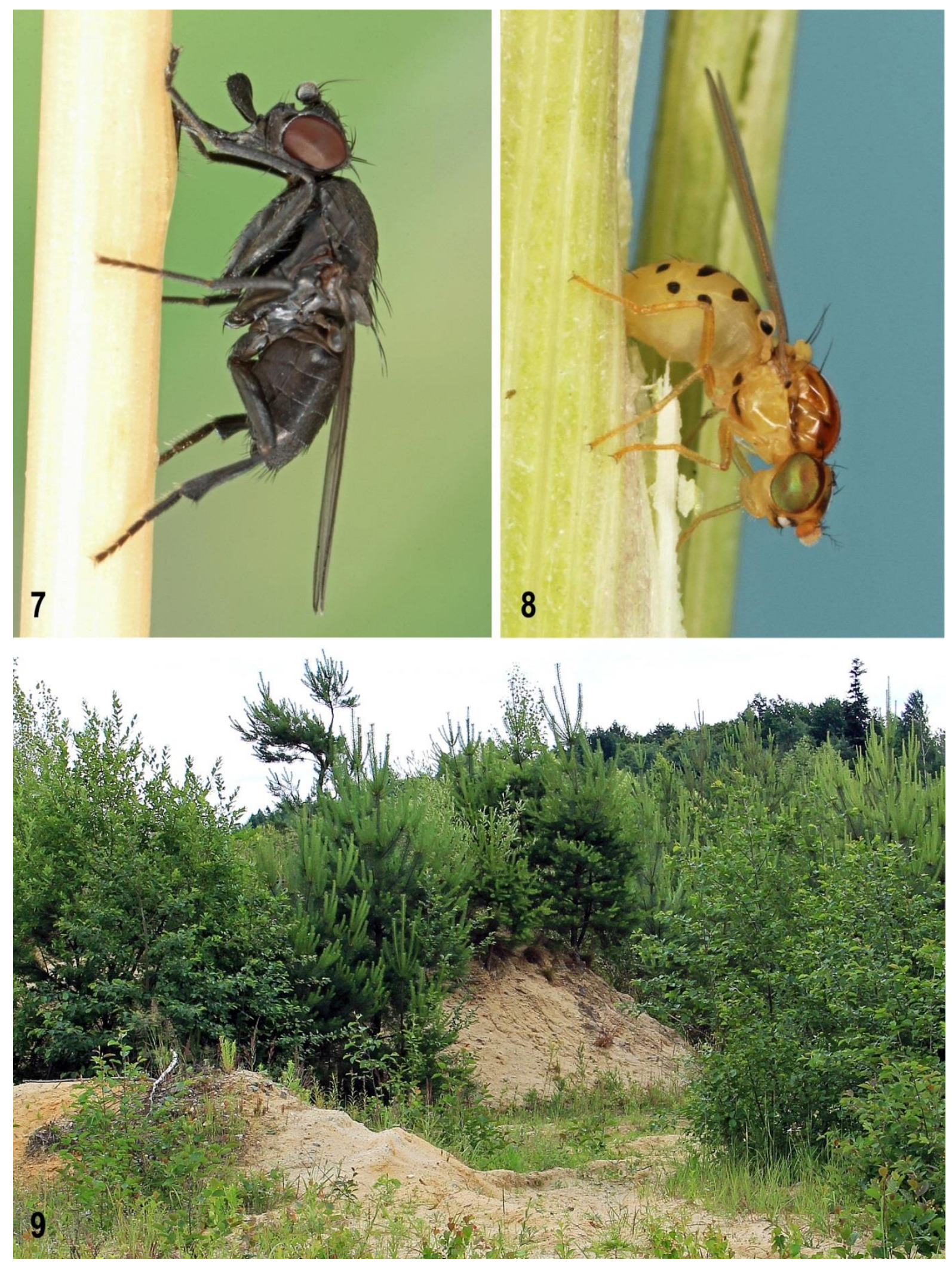

Figs 7-9: Desmometopa discipalpis Papp and Asteia elegantula Zetterstedt and their habitat. 7 - D. discipalpis, male in lateral view, body length $3.1 \mathrm{~mm} ; \mathbf{8}-A$. elegantula, female in lateral view, body length $2.1 \mathrm{~mm}$; 9 - marginal part of young forest on bottom of SW part of the sandpit Závada, habitat of both these species. Photo by J. Roháček. 
from other types of sandy habitats, including those in sandpits as are the above or that by Kubík (2013). Therefore, E. variegata can be treated as a psammophilous or even a psammobiont species. The majority of specimens recorded above were swept from sparse low vegetation on a dune-like sand heap in NW part of the sandpit under study (see Fig. 12).

Distribution: In Europe the species has been recorded from Germany, Switzerland, Austria, Czech Republic, Poland, Slovakia, Hungary, Slovenia, Bulgaria, Ukraine, Norway, Finland, Estonia, Russia (CET, NET, SET) (Nartshuk \& Andersson 2013; Nartshuk 2013; Kubík 2013); it is also known from Central Asia (Nartshuk \& Andersson 2013). Interestingly, E. variegata was described (Loew 1866) from Reinerz (now Duszniki Zdrój) in Polish Silesia, thus not very far from the sandpit Závada (in Czech Silesia). First record from the Czech Republic was given by Kubík (2013) based on finding by B. Mocek in a former sandpit near Veselská (E Bohemia). The above records (first from Moravia) confirm the occurrence of the species in the Czech Republic.

\section{CURTONOTIDAE}

\section{Curtonotum anus (Meigen, 1830) (Fig. 13)}

Material examined: CZECH REPUBLIC: N Moravia: Závada nr. Hlučín 1.6 km S, 4956'25"N, 1809'56"E,

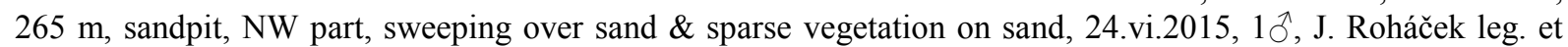
det. (SMOC, photographed).

Biology: Adults of C. anus are known to be associated with sandy habitats in Hungary (Papp 1998b) and often occur on sandy or muddy shaded river banks in the Mediterranean area (personal observation from Italy: Calabria and Turkey: Antalya) including Israel (KirkSpriggs \& Freidberg 2007). They were also found on dung on sand dunes in Turkey (Ozerov \& Krivosheina 2013). Its larvae are probably scavengers in egg pods of locusts as is known for the Nearctic C. helvum (Loew, 1862) and some African species (cf. Meier et al. 1997). Adults of $C$. anus obviously are similarly crepuscular or even nocturnal, hidden and inactive in shaded places during daylight hours like the other species of the genus (Marshall 2012). They can be attracted to decayed substrates (like dung, insect carcasses etc.) as also is known in C. helvum (see Meier et al. 1997). It is to note that the majority of Central European records of $C$. anus are from sandy or muddy shores of rivers, including those by Martinek (1982) who found adults sitting on the bark of a fallen poplar trunk on the bank of the Morava river (SE Czech Republic, see below). The only male of $C$. anus recorded from Závada sandpit was netted in the afternoon from sparse low vegetation on sand shaded by a small willow tree (see Fig. 14). A special trip is therefore planned to this locality for June and/or July 2016, aimed at collection at dusk to test the crepuscular activity of $C$. anus.

Distribution: A largely SW Palaearctic species. Its current distribution is summarized by Ozerov \& Krivosheina (2013) who found data given in FaEu (Carles-Tolrá 2013b) incomplete and those from the Far East of Russia (Sidorenko 2001) and Japan (Okada 1960) erroneous because they were based on misidentifications of other species. Consequently, based on Ozerov \& Krivosheina (2013), Carles-Tolrá (2013b) and data in TaxoDros (Bächli 2015) C. anus has been known from Spain, France, Italy, Austria, Czech Republic (S Moravia only), Poland, Slovakia, Hungary, Serbia, Albania, Romania, Bulgaria, Greece, Russia (SET), Israel, Turkey, Turkmenistan, Kazakhstan and Pakistan. However, Sidorenko (2001) also listed Georgia, Armenia, Azerbaidjan, Tadzhikistan and Mongolia, all of which, except Mongolia, are within the above distribution range and may also be reliable. 

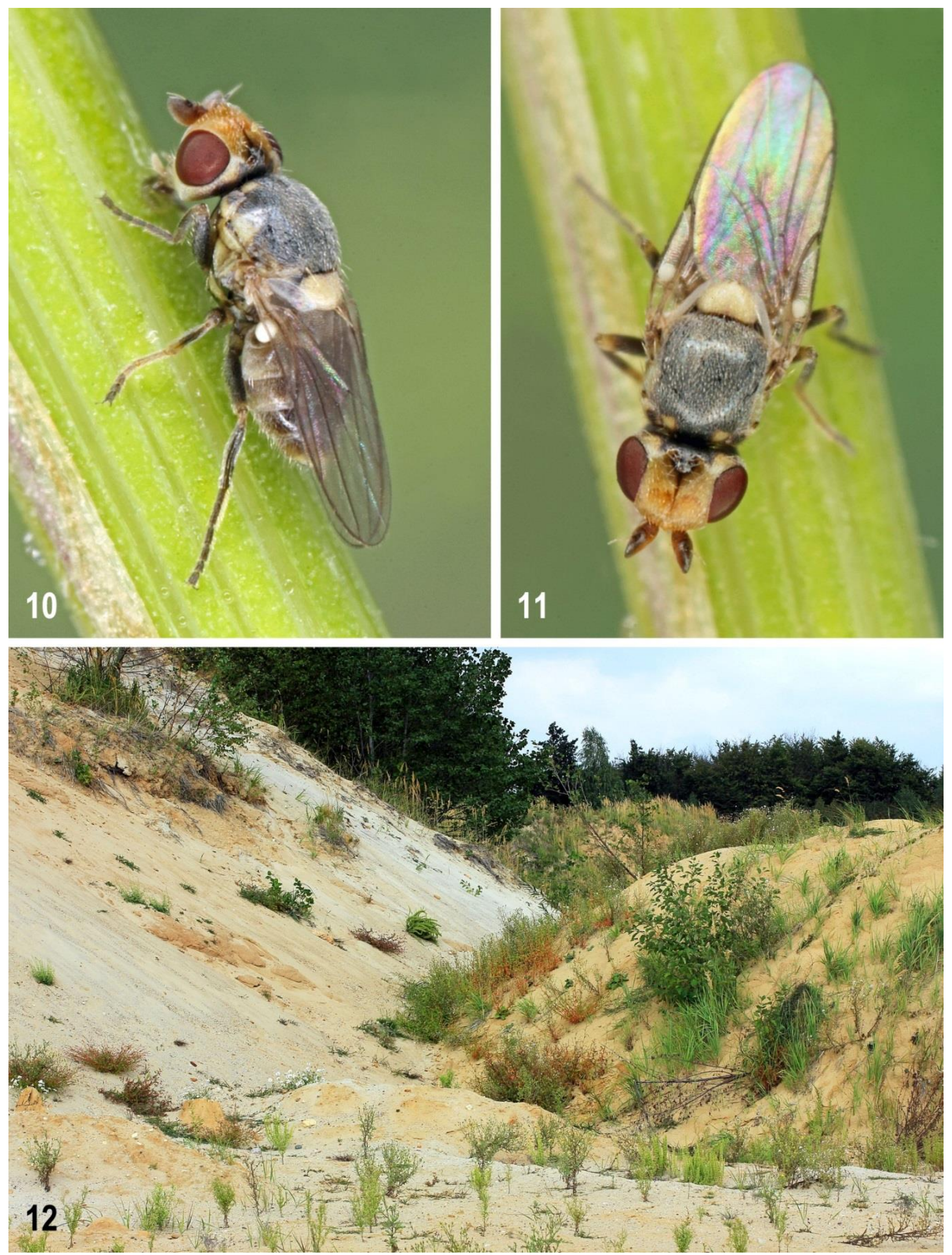

Figs 10-12: Eutropha variegata Loew, and its habitat. 10 - female E. variegata in lateral view, body length 2.0 $\mathrm{mm} ; \mathbf{1 1}$ - the same in dorsal view; $\mathbf{1 2}$ - heaps of sand with various sparse vegetation in NW part of the sandpit, habitat of E. variegata. Photo by J. Roháček. 
Apparently, the northernmost occurrence of $C$. anus is based on an old record from Poland: Warszawa (Sznabl 1881) which was, however, overlooked by Ozerov \& Krivosheina (2013) but included in the checklists of Diptera of Poland (Nowakowski 1991; Chudzicka \& Skibińska 2007) and also in Fauna Europaea (Carles-Tolrá 2013).

C. anus is a rare species in Central Europe (see Máca 2009), particularly in its more northern parts. In the Czech Republic it was only recorded from Strážnice-př́ívoz (correctly Bzenec-př́ivoz nr Strážnice) in S Moravia (Martinek 1982, 1984). Also records from Slovakia (summarized by Martinek 1986) are scarce and yet older, viz. Bolesó (= Bolešov nr. Trenčín) (Brancsik 1910), Pistyan (= Piešt’any) (Oldenberg 1914), Roszahegy (= Ružomberok) (Soós 1946), similarly as is that from Austria: Tirol (Dalla Torre 1918). The locality Závada sandpit (first from the Czech Silesia, NE Czech Republic) is currently the northermost occurrence site of $C$. anus inasmuch as the old record from Warszawa (Sznabl 1881) remains unconfirmed by more recent findings.

Comments: Because of its association with sandy habitats Curtonotum anus seems to be a psammophilous species. Its finding on glacial sands in the Hlučínsko area was rather surprising, not only because of the high latitude for this thermophilous and largely southern species but also due to the absence of a river in the locality Závada. However, it is to note that this sandpit is not extremely dry - in spring or after heavy rains there are even temporary pools in its bottom so that also species requiring more humidity do occur there. Further, if $C$. anus is a dark-loving species with adults active in evening and night it could be passed unnoticed by dipterists in other suitable habitats and hence considered so rare in Central Europe.

\section{Discussion and conclusions}

Sandy habitats in the Hlučínsko area (NE Czech Republic) were formed on the glaciolacustrine sand deposits after the largest (Saalian) glaciation cca 160000 ya on shores of postglacial lakes which had arisen from a melted glacier (for more detail see (Růžičková et al. 2001; Nývlt et al. 2011). The psammophilous insect fauna occurs here mainly in sites where the sand is exposed, i.e. mostly in sandpits and adjacent non-cultivated spots of land. The former accidental samplings of Diptera in these habitats provided interesting results, including findings of a few psammophilous or even psammobiont species, viz. Aspistes berolinensis Meigen, 1818 (fam. Scatopsidae), Pamponerus germanicus (Linnaeus, 1758) (Asilidae) or Trixoscelis obscurella (Fallén, 1823) (Trixoscelididae) in the abandoned sandpit Bělá ve Slezsku or Anthrax varius Fabricius, 1794 (Bombyliidae) in the active sandpit Závada (Roháček \& Ševčík 2013).

A more systematic field work in these two sandpits and their close vicinity devoted to sand-loving flies was realized in the area in 2013 and 2015. Results dealing with the most interesting findings presented by Roháček $(2015 \mathrm{a}, \mathrm{b})$ and in this study clearly demonstrated that glacial sand habitats in the area under study host a specific fly community. Most characteristic are taxa closely associated with the local sandy ecosystem (psammobiont and psammophilous species) which were largely ascertained in microhabitats most resembling sand dunes (see Figs 4, 12). Also thermophilous and/or xerophilous species, including several occurrences which had not been expected in this area (cf. Roháček $2015 \mathrm{~b}$ and those recorded above), proved to form an important component of the fly community in the sandpits under study.

Judging from their distribution the sand-loving species ascertained on glacial sands in the Hlučínsko area are considered to be of different origins. Besides the species of distinctly southern origin (e.g. Curtonotum anus, Desmometopa discipalpis) and taxa widespread in the 

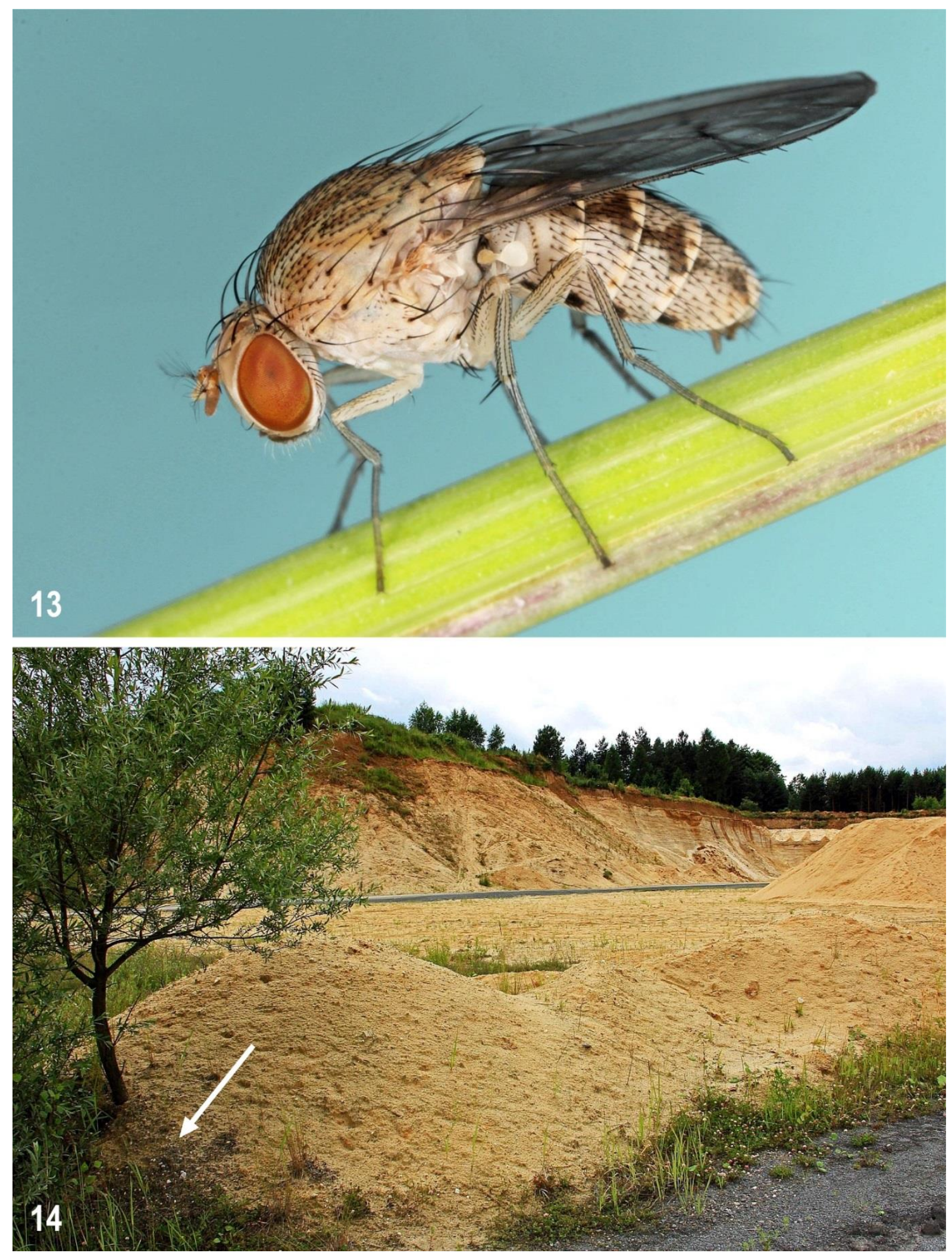

Figs 13-14: Curtonotum anus (Meigen) and its habitat. 13 - male C. anus in lateral view, body length $5.7 \mathrm{~mm}$; 14 - collecting spot of $C$. anus (arrow) under a young willow in NW part of the Závada sandpit. Photo by J. Roháček. 
W Palaearctic (e.g. Aspistes berolinensis, Asteia elegantula, Trixoscelis obscurella, Eutropha variegata), it seems that at least some of them could have spread from the Baltic Sea coastal area by a growing continental glacier during the Saalian Glaciation and survived on sand dunes formed on the shores of postglacial lakes up to the present. Such a northern origin can be attributed to Tetanops myopina, a maritime species living on sand dunes of the Irish, North and Baltic Seas having its only inland populations on glacial sands in northern Ukraine and the NE part of the Czech Republic (Roháček 2015a) and possibly also to Anthomyza elbergi being widespread in the northern belt of the Palaearctic Region and having its closest European localities in N Germany and NE Poland. Populations of these two species on glacial sand deposits in NE Czech Republic can therefore be considered glacial relicts unless they will be discovered in intervening areas of Poland.

The results presented above show distinctly that dipterous communities on sandy habitats in Central Europe, particularly on those of glacial origin, are worthy of further study because it may provide much new and important information about the postglacial evolution of the insect fauna in this region.

Acknowledgements: I would like to express my gratitude to I. Brake (London, England), J. Máca (České Budějovice, Czech Republic), Š. Kubík (Praha, Czech Republic), A. L. Ozerov (Moscow, Russia) and L. Papp (Budapest, Hungary) for confirmation of identifications, comments on manuscript and/or help with literature. P. Chandler (Melksham, England) is thanked for all improvements, additions and language corrections of the paper. The author's study was financially supported by the Ministry of Culture of the Czech Republic by institutional financing of long-term conceptual development of the research institution (the Silesian Museum, MK000100595), internal grant of the Silesian Museum No. IGS201607/2016.

\section{References}

Andersson H. (1976): Revision of the Anthomyza species of Northwest Europe (Diptera: Anthomyzidae) I. The gracilis group. - Entomol. Scand. 7: 41-52.

Bächli G. (2015): TaxoDros - the database on taxonomy of Drosophilidae. Database 2015/03; TaxoDros v1.04, http://www.taxodros.uzh.ch/index.php, accessed on 10.i.2016

Brake I. (2009): The type material of Milichiidae and Carnidae (Insecta: Diptera: Schizophora) in the Naturhistorisches Museum Wien. - Annls Naturhist. Mus. Wien (B), 110: 67-76.

- (2010): Milichiidae of the Lake Kerkini region in Greece. Milichiidae online, http://milichiidae.info/ content/milichiidae-lake-kerkini-region-greece, accessed on 6.i.2016

Brancsik K. (1910): A Trencsénvármegyeben talált Dipterák felsorolása [List of Diptera found in Trenčín county]. - Trencs. Várm. Termész. Eg. Trencsén 31-33(1908-1910): 127-158 (in Hungarian).

Carles-Tolrá M. (2013a): Fauna Europaea: Asteiidae. In Beuk P. \& Pape T. (eds): Fauna Europaea: Diptera Brachycera. Fauna Europaea version 2.6, http://www.fauna-eu.org, accessed on 6.i.2016

- (2013b): Fauna Europaea: Curtonotidae. In Beuk P. \& Pape T. (eds): Fauna Europaea: Diptera Brachycera. Fauna Europaea version 2.6, http://www.fauna-eu.org, accessed on 6.i.2016

Chudzicka E. \& Skibińska E. (2007): Curtonotidae. P. 216. In Bogdanovicz W., Chudzicka E., Pilipiuk I. \& Skibińska E. (eds): Fauna Polski. Charakterystyka I wykaz gatunków. Fauna of Poland. Characteristics and checklist of species. Vol. 2. Muzeum i Institut Zoologii PAN, Warszawa, 505 pp.

Dalla Torre K.W. von (1018): Systematisches Verzeichnis der Dipteren Tirols. - Entomol. Jahrb. 27: 148-163.

Kirk-Spriggs A. H. \& Freidberg A. (2007): The Palaearctic species of Curtonotidae (Diptera: Schizophora), with special reference to the fauna of Israel. - Bull. Inst. R. Sci. Nat. Belg. (Entomol.) 77: 133-146.

Kubík Š. (2009): Chloropidae Rondani, 1856. In Jedlička L., Kúdela M. \& Stloukalová V. (eds): Checklist of Diptera of the Czech Republic and Slovakia. Electronic version 2. http://www.edvis.sk/ diptera2009/ families/chloropidae.htm + CD-ROM: ISBN 978-80-969629-4-5.

- (2013): New records of Chloropidae (Diptera) from the Czech and Slovak Republics. - Čas. Slez. Muz. Opava (A) 62: 274-276.

Loew (1866): Über die bisher in Schlesien aufgefundenen Arten der Gattung Chlorops Macq. - Ztschr. Entomol. Breslau, 15(1861), Jahrgang 20: 3-96.

Máca J. (2009): Curtonotidae Enderlein, 1914. In Jedlička L., Kúdela M. \& Stloukalová V. (eds): Checklist of Diptera of the Czech Republic and Slovakia. Electronic version 2. http://www.edvis.sk/ diptera2009/ families/curtonotidae.htm + CD-ROM: ISBN 978-80-969629-4-5.

Marshall S.A. (2012): Flies: the natural history \& diversity of Diptera. Firefly Books, Richmont Hill, Buffalo, $616 \mathrm{pp}$. 
Martinek V. (1982): Discovery of some new species of Diptera - Acalyptrata in the fauna of Czechoslovakia. - Folia Fac. Sci. Nat. Univ. Purk. Brun. 23(7), Biologia 74: 75-81.

- (1984): K poznání jarního společenstva dvoukřídlých (Diptera - Acalyptrata) v povodí řeky Moravy. A contribution to the knowledge of the Diptera - Acalyptrata spring assemblage on the Morava river banks, southern Moravia. - Čas. Nár. Muz., ř. př́rod. 153: 49-54 (in Czech with English summary).

- (1986): Čel'ad': Curtonotidae. P. 116. In Čepelák J. (ed.): Diptera Slovenska II. Veda, Bratislava, 435 pp. (in Slovak).

Meier R., Kotrba M. \& Barber K. (1997): A comparative study on the egg, first instar larva, puparium, female reproductive systém and natural history of Curtonotum helvum (Curtonotidae; Ephydroidea; Diptera). - Am. Mus. Novitates 3219: 1-20.

Nartshuk E.P. (1987): Zlakovye mukhi (Diptera: Chloropoidea). Ikh sistema, evoljucija i svjazi s rastenijami. [The frit flies (Diptera: Chloropoidea). Their system, evolution and host plant associations]. Trudy Zoologicheskogo Instituta Akademii nauk SSSR, Vol. 136, Nauka, Leningrad, 279 pp.

- (2013): Fauna Europaea: Chloropidae. In Beuk P. \& Pape T. (eds): Fauna Europaea: Diptera Brachycera. Fauna Europaea version 2.6, http://www.fauna-eu.org.

Nartshuk E.P. \& Andersson H. (2013): The frit flies (Chloropidae, Diptera) of Fennoscandia and Denmark. Fauna Entomologica Scandinavica, Vol. 43, Brill, Leiden, Boston, 282 pp.

Nowakowski J.T. (1991): Curtonotidae. Pp. 227-228. In Razowski J. (ed.): Checklist of animals of Poland [Wykaz zwierzat Polski], Vol. 2. Polska Akademia Nauk, Ossolineum, Wrocław, Warszawa, Kraków, 342 pp.

Nývlt D, Engel Z. \& Tyráček J. (2011): Chapter 4. Pleistocene glaciation in Czechia. Pp. 37-45. In Ehlers J., Gibbart P.L. \& Hughes P.D. (eds): Quaternary Glaciations - extent and chronology: a closer look. Elsevier, Amsterdam, 1108 pp.

Okada T. (1960): Notes on Diastatidae from Japan (Diptera). - Kontyû 28: 165-167.

Oldenberg L. (1914): Beitrag zur Kenntnis der europaischen Drosophiliden (Dipt.). - Arch. Naturgesch. $80(\mathrm{~A})(2): 1-42$.

Ozerov A.L. \& Krivosheina M.G. (2013): Curtonotidae (Diptera) of Russia. - Russian Entomol. J. 22(2): $149-154$

Papp L. (1993): Three new milichiid species from Hungary. - Annls Hist.-Nat. Mus. Natn. Hung. 85: 133-139.

- (1998a): 3.25. Family Asteiidae. Pp. 295-308. In Papp L. \& Darvas B. (eds): Contributions to a Manual of Palaearctic Diptera. Vol. 3., Higher Brachycera. Science Herald, Budapest, 880 pp.

- (1998b): 3.44. Family Curtonotidae. Pp. 497-502. In Papp L. \& Darvas B. (eds): Contributions to a Manual of Palaearctic Diptera. Vol. 3., Higher Brachycera. Science Herald, Budapest, 880 pp.

Panteleeva N.Yu. (1997): K faune i ekologii mukh antomizid (Diptera, Anthomyzidae) Tsentral'nogo Chernozem'ya. [To the fauna and ecology of the anthomyzid flies (Diptera, Anthomyzidae) of the Central Chernozem territory]. In: Sostojanie i problemy ekosistem Srednego Podon'ya. Trudy biologicheskogo ychebno-nauchnogo tsentra Voronezhkogo gosudarstvenogo universiteta „Venevitinovo“, 10: 84-87 (in Russian).

- (2005): Semeistvo Anthomyzidae [Family Anthomyzidae]. Pp. 428-429. In Negrobov O. P. (ed.): Kadastr bespozvonochnykh zhivotnykh Voronezhkoi oblasti. [Cadastre of invertebrate animals of the Voronezh region]. Voronezhkii gosudarstvennyi universitet, Voronezh, 825 pp. (in Russian).

Panteleeva N.Yu. \& Razvorotnev D.V. (1996): K izucheniyu nekotorykh semeistv korotkousykh dvukrylykh Tsentral'nogo Chernozem'ya. [To the knowledge of some families of brachycerous Diptera of the Central Chernozem territory]. In: Sostojanie i problemy ekosistem Srednego Podon'ya. Trudy biologicheskogo ychebno-nauchnogo tsentra Voronezhkogo gosudarstvenogo universiteta „Venevitinovo“, 8: 127-132 (in Russian).

Roháček J. (1980): Faunistic records from Czechoslovakia. Diptera, Asteiidae. - Acta Entomol. Bohemoslov., 77: 347.

- (1985): New and/or interesting records of Diptera Acalyptrata (Strongylophthalmyiidae, Megamerini-dae, Chamaemyiidae, Trixoscelididae, Chyromyidae, Anthomyzidae, Asteiidae, Milichiidae, Carnidae) from Czechoslovakia. - Čas. Slez. Muz. Opava (A) 34: 193-201.

- (1999): Asteiidae. In Rozkošný R. \& Vaňhara J. (eds): Diptera of the Pálava Biosphere Reserve of UNESCO II. - Fol. Fac. Sci. Nat. Univ. Masaryk. Brun., Biologia 100: 321-323

- (2005): Asteiidae (suchobytkovití). P. 335. In Farkač J., Král D. \& Škorpík M. (eds): Červený seznam ohrožených druhů České republiky. Bezobratlí. Red list of threatened species in the Czech Republic. Invertebrates. Agentura ochrany př́rody a krajiny České republiky, Praha, 760 pp.

- (2006): A monograph of Palaearctic Anthomyzidae (Diptera) Part 1. - Čas. Slez. Muz. Opava (A) 55, suppl. 1: $1-328$.

- (2009a): Anthomyzidae Czerny, 1903. In Jedlička L., Kúdela M. \& Stloukalová V. (eds): Checklist of Diptera of the Czech Republic and Slovakia. Electronic version 2. http://www.edvis.sk/diptera2009/ families/ 
anthomyzidae.htm + CD-ROM: ISBN 978-80-969629-4-5.

- (2009b): Asteiidae Rondani, 1856. In Jedlička L., Kúdela M. \& Stloukalová V. (eds): Checklist of Diptera of the Czech Republic and Slovakia. Electronic version 2. http://www.edvis.sk/diptera2009/ families/asteiidae.htm + CD-ROM: ISBN 978-80-969629-4-5.

- (2009c): Milichiidae Schiner, 1862. In Jedlička L., Kúdela M. \& Stloukalová V. (eds): Checklist of Diptera of the Czech Republic and Slovakia. Electronic version 2. http://www.edvis.sk/diptera2009/ families/milichiidae.htm + CD-ROM: ISBN 978-80-969629-4-5.

- (2009d): Ulidiidae Macquart, 1835. In Jedlička L., Kúdela M. \& Stloukalová V. (eds): Checklist of Diptera of the Czech Republic and Slovakia. Electronic version 2. http://www.edvis.sk/diptera2009/ families/ulidiidae.htm + CD-ROM: ISBN 978-80-969629-4-5.

- (2009e): A monograph of Palaearctic Anthomyzidae (Diptera) Part 2. - Čas. Slez. Muz. Opava (A) 58, suppl. 1: $1-180$.

- (2015a): Tetanops myopina Fallén, 1820, a psammophilous species of Otitinae (Diptera: Ulidiidae) found in a sandpit in the northeastern part of the Czech Republic. - Acta Mus. Siles. Sci. Nat. 64: 1-10.

- (2015b): Psammophilous flies (Diptera) on glacial sand deposits in Silesia (Czech Republic). P. 33. In Hamerlík L., Dobríková D. \& Stoklasa J. (eds): The 8th Central European Dipterological Conference: conference abstracts (Kežmarské Žl'aby, 28.-30. September 2015). Belianum, Banská Bystrica, 79 pp.

Roháček J. \& Barták M. (2001): Asteiidae. In Barták M. \& Vaňhara J. (eds): Diptera in an industrially affected region (north-western Bohemia, Bílina and Duchcov environs), II. - Folia Fac. Sci. Nat. Univ. Masaryk. Brun., Biologia 105: 381-384.

Roháček J., Barták M. \& Kubík Š. (2013): Acartophthalmidae, Asteiidae, Aulacigastridae, and Pseudopomyzidae (Diptera) of Vráž nr. Písek (Czech Republic). Pp. 314-322. In Kubík Š. \& Barták M. (eds): Workshop on biodiversity, Jevany. Česká zemědělská universita v Praze, 436 pp.

Roháček J., Kubík Š. \& Barták M. (2005): Asteiidae. Pp. 309-311. In Barták M. \& Kubík Š. (eds): Diptera of Podyjí National Park and its Environs. Česká zemědělská univerzita v Praze, Praha, 434 pp.

Roháček J. \& Ševčík J. (2013): Dvoukřídlí (Diptera). Pp. 263-283. In Roháček J., Ševčík J. \& V1k P. (eds): Př́roda Slezska [Nature of Silesia]. Slezské zemské muzeum, Opava, 480 pp. (in Czech).

Růžičková E., Růžička M., Zeman A. \& Kadlec J. (2009): Quaternary clastic sediments of the Czech Republic. Textures and structures of the main genetic type. Český geologický ústav, Praha, $68+92 \mathrm{pp}$.

Sabrosky C.W. (1983): A synopsis of the world species of Desmometopa Loew (Diptera, Milichiidae). Contr. Am. Entomol. Inst. 19(8): 1-69.

Sidorenko V.S. (2001): 110. Sem. Curtonotidae. Pp. 178-179. In Ler P. A.(ed.): Opredelitel' nasekomykh Dalnego Vostoka Rossii. Vol. 6, Pt. 2. Dvukrylye i blochi. [Key to the insects of Russian Far East. Vol. 6, Pt. 2. Diptera and Siphonaptera, Dal'nauka, Vladivostok (in Russian).

Soós Á. (1946): Die acalypteren Musciden des Karpatenbeckens. III. 7. Megamerinidae, 8. Psilidae, 9. Tanypezidae, 10. Trichoscelidae, 11. Anthomyzidae, 12. Periscelidae, 13. Astiidae, 14. Aulacogastridae, 15. Curtonotidae, 16. Camillidae. - Fragm. Faun. Hung. 9: 2-10.

Sznabl J. (1881): Spis owadów dwuskrzydłych zebranych w Królestwie Polskim i Gubernii Mińskiej [List of two-winged flies (Diptera) collected in Kingdom of Poland and the Minsk government]. - Pam. Fizjogr. Warszawa, 1: 357-390 (in Polish).

\section{Akalyptrátní dvoukřídí (Diptera) na ložiskách glaciálních písků v oblasti Hlučínska (Česká republika): nejzajímavější nálezy}

V př́spěvku jsou prezentovány nálezy šesti zajímavých druhů čeledí Ulidiidae, Anthomyzidae, Asteiidae, Milichiidae, Chloropidae a Curtonotidae, které byly objeveny při výzkumu dipterofauny na glaciálních pískách ve dvou pískovnách (Bělá ve Slezsku, Závada) na Hlučínsku (severovýchodní část České republiky) a diskutována jejich vazba na písčité biotopy. Dva teplomilné a suchomilné druhy, Anthomyza elbergi Andersson, 1976 (Anthomyzidae) a Desmometopa discipalpis Papp, 1993 (Milichiidae) jsou novými druhy pro faunu České republicky. Dva psamofilní (pískomilné) či dokonce psamobiontní druhy, Eutropha variegata Loew, 1866 (Chloropidae) a Curtonotum anus (Meigen, 1830) (Curtonotidae) jsou poprvé ohlášeny z Moravy, respektive z Českého Slezska, přičemž posledně jmenovaný druh je uveden z lokality ležící na severním okraji svého areálu rozšiřrení. Také Asteia elegantula Zetterstedt, 1847 (Asteiidae) je poprvé zaznamenána v Českém Slezsku a Desmometopa discipalpis zde byla zjištěna na nejsevernějš́ známé lokalitě. Jsou podány informace o mikrobiotopech všech těchto druhů (včetně psamobiontního Tetanops myopina Fallén, 1820, Ulidiidae) ve zkoumaných pískovnách a prezentovány fotografie živých jedinců většiny z nich. Je diskutován také původ populací těchto druhů na Hlučínsku se závěrem, že zatímco Asteia elegantula a Eutropha variegata jsou druhy široce rozšířené v západní části Palearktické oblasti, jiné dva druhy, Curtonotum anus a Desmometopa discipalpis, jsou jasně jižního původu. Nejzajímavější z tohoto hlediska jsou Tetanops myopina a Anthomyza elbergi, které se na Hlučínsko rozšířili patrně ze severu, a to pravděpodobně již v době Saalského zalednění (před asi 160000 lety), kdy sem byly zatlačeny narůstajícím kontinentálním ledovcem.

Author's address: Jindřich R o h á č e k, Silesian Museum, Nádražní okruh 31 CZ-746 01 Opava, Czech Republic. E-mail: rohacek@szm.cz 